\title{
RZECZPOSPOLITA POLSKA DOBREM WSPÓLNYM WSZYSTKICH OBYWATELI*
}

I. Niniejsze opracowanie jest wkładem do dyskusji na temat normatywnego znaczenia art. 1 Konstytucji i propozycją metodologii badań nad konstytucyjna zasada, która głosi, że „Rzeczpospolita Polska jest dobrem wspólnym wszystkich obywateli”.

Dotychczasowy punkt wyjścia w dyskusji na ten temat jest błędny przede wszystkim dlatego, że rozważa się pojęcie dobra wspólnego w kontekście pojęć synonimicznych, takich jak dobro ogółu, interes społeczny, interes publiczny, bez uwagi, że art. 1 Konstytucji pojęcie dobra wspólnego łączy z państwem, inaczej mówiąc, że art. 1 państwo nazywa dobrem wspólnym. I po drugie dlatego, że próbuje się za pomoca pojęć ustawowych ${ }^{1}$ opisać treść pojęcia konstytucyjnego, choć wiadomo, że pojęcia konstytucyjne maja autonomiczny sens i wobec ustaw nadrzędny.

Artykuł 1 Konstytucji RP, który stanowi, że „Rzeczpospolita Polska jest wspólnym dobrem wszystkich obywateli” zamieszczony w rozdz. I: Rzeczpospolita, wyraża podstawowa zasadę ustroju naszego państwa. Jest on pomieszczony wśród takich zasad, jak: zasada państwa prawnego (art. 2), zasada zwierzchnictwa narodu (art. 4), zasada legalności i praworządności (art. 7), zasada, według której Konstytucja jest najwyższym prawem i że jej przepisy są bezpośrednio stosowane (art. 8). Wyliczone tu zasady nie wyczerpuja wszystkich zawartych w rozdz. I Konstytucji ${ }^{2}$.

Owo wyliczenie jest potrzebne, aby powiedzieć, że treść normatywna wszystkich spośród wymienionych zasad została w literaturze prawa konstytucyjnego opisana albo dlatego, że sama zasada została w miarę jasno wyrażona w Konstytucji (np. art. 7), albo dlatego, że orzecznictwo Trybunału Konstytucyjnego, Sądu Najwyższego i Naczelnego Sądu Administracyjnego - pozwoliło opisać treść tej zasady (np. art. 2 czy art. 8 Konstytucji).

* Artykuł za zgodą Wydawcy opiera się na tekście autora Rzeczpospolita Polska dobrem wspólnym wszystkich obywateli, który ukazał się w pracy zbiorowej Sadownictwo administracyjne gwarantem wolności i praw obywatelskich 1980-2005, pod red. J. Górala, R. Hausera, J. Trzcińskiego, Wyd. NSA, Warszawa, s. 452-460.

${ }^{1}$ Zob. np. R. Sowiński, Interes publiczny - dobro wspólne. Wartości uniwersalne jako kategorie kształtujace pojęcie administracji, w: Z. Niewiadomski, Z. Cieślak (red.), Prawo do dobrej administracji, Warszawa 2003.

${ }^{2}$ Zob. wyczerpujace opracowanie na temat zasad podstawowych w Konstytucji z 1997 r. Zasady podstawowe Polskiej Konstytucji, Warszawa 1998. Co charakterystyczne, w opracowaniu tym nie omawia się zasady zawartej w art. 1 Konstytucji. 
Rzecz przedstawia się zgoła inaczej, gdy idzie o art. 1 Konstytucji. Nie ma dotąd ani w ramach prawa konstytucyjnego ${ }^{3}$, ani w orzecznictwie sądowym prób zdekodowania treści normatywnej zasady w nim wyrażonej.

Zakładam jednak, że tak jak inne zasady ustrojowe wyrażone w naszej Konstytucji także zasada, według której Rzeczpospolita jest dobrem wspólnym wszystkich obywateli, ma swoją treść, i że art. 1 Konstytucji ma określony walor prawny, i to nie tylko dlatego, że jest zamieszczony w tekście Konstytucji.

Przy braku definicji legalnej pojęcia „dobro wspólne” punktem wyjścia odpowiedzi na pytanie o treść zasady zawartej w art. 1 musi być analiza także innych przepisów Konstytucji.

Otóż obok art. 1 pojęcie dobra wspólnego w kontekście Rzeczypospolitej użyte jest dwukrotnie we wstępie do Konstytucji: w zdaniu, że „wszyscy obywatele Rzeczypospolitej [...] równi w prawach i w powinnościach wobec dobra wspólnego - Polski [...] ustanawiamy Konstytucję Rzeczypospolitej Polskiej" oraz w zdaniu „Wszystkich, którzy dla dobra Trzeciej Rzeczypospolitej tę Konstytucję będa stosowali, wzywamy, aby czynili to, dbając o zachowanie przyrodzonej godności człowieka, jego prawa do wolności i obowiązku solidarności z innymi, a poszanowanie tych zasad mieli za niewzruszona podstawę Rzeczypospolitej Polskiej”, a także w art. 25 ust. 3 Konstytucji: „Stosunki między państwem a kościołami i innymi związkami wyznaniowymi sa kształtowane na zasadach poszanowania ich autonomii oraz wzajemnej niezależności każdego w swoim zakresie, jak również współdziałania dla dobra człowieka i dobra wspólnego” oraz w art. 82 Konstytucji: „obowiązkiem obywatela polskiego jest wierność Rzeczypospolitej Polskiej oraz troska o dobro wspólne". Cytowane przepisy Konstytucji użyte razem nie ułatwiają zdekodowania treści i znaczenia prawnego art. 1 Konstytucji, choć pewne refleksje w oczywisty sposób się nasuwaja:

a) dobrem wspólnym jest Rzeczpospolita Polska, Polska - a więc państwo polskie. Ta konstatacja jest ważna dla propozycji badań nad zagadnieniem zawartym w art. 1 Konstytucji, która musi uwzględniać konstytucyjną koncepcję państwa,

b) dobro wspólne jako wartość konstytucyjna ujęte jest w Konstytucji w obszarze zasad ustroju państwa oraz w obszarze wolności, praw i obowiązków jednostki i ma służyć wszystkim obywatelom,

c) zasada, że Rzeczpospolita Polska (Polska) jest dobrem wspólnym, jest w systematyce Konstytucji przed innymi zasadami ustrojowymi, w tym przed zasadą demokratycznego państwa prawnego.

${ }^{3}$ Literatura prawnicza dotycząca zagadnienia art. 1 Konstytucji, a więc Rzeczypospolitej Polskiej jako dobra wspólnego wszystkich obywateli, jest jak dotąd bardzo uboga. Poza wzmiankami na ten temat w podręcznikach do nauki prawa konstytucyjnego można by wskazać następujące pozycje: „Rzeczpospolita dobrem wspólnym wszystkich obywateli” (wystapienie Prezydenta Aleksandra Kwaśniewskiego w Trybunale Konstytucyjnym), „Państwo i Prawo” 2005, z. 6; B. Lewaszkiewicz-Petrykowska, Dobro wspólne versus konstytucyjne prawa i wolności jednostki, w: Konferencja Trybunału Konstytucyjnego Rzeczypospolitej Polskiej i Sadu Konstytucyjnego Republiki Litewskiej (Śreniawa 26-29.VI.2002), „Studia i Materiały” 17, 2003; A. Piechowiak, Filozoficzne podstawy rozumienia „dobra wspólnego”, „Kwartalnik Filozoficzny” 2003, nr 2; R. Sowiński, op. cit.; A. Szpor, Odwaga stużenia dobru wspólnemu, w: Z. Niewiadomski, Z. Cieślak (red.), op. cit. 
Uogólniając powyższe spostrzeżenia, należy powiedzieć, że gdy mówimy o dobru wspólnym w kontekście art. 1 Konstytucji, to mówimy o państwie, o jednostce, a przede wszystkim o relacji pomiędzy tymi podmiotami i że relacja ta nie redukuje się do płaszczyzny wolności, praw i obowiązków jednostki i przyczyn oraz metod ich ograniczania.

II. Dekodując treść normatywną art. 1 Konstytucji, należy pomocniczo sięgnąć do polskiej praktyki konstytucyjnej, a także do dyskusji w Komisji Konstytucyjnej $\mathrm{ZN}^{4}$ nad pojęciem państwa jako „dobra wspólnego” i wyrażonych przy tej okazji poglądów.

W trakcie debaty konstytucyjnej zwrócono uwagę, że pojęciem dobra wspólnego posługiwała się Konstytucja Polski z 1935 r. W art. 1 stanowiła, że „Państwo Polskie jest wspólnym dobrem wszystkich obywateli”. Na tle tak brzmiącej formuły dostrzega się zasadniczą różnicę pomiędzy art. 1 Konstytucji z 1997 r. a art. 1 Konstytucji z 1935 r. Różnica ta uzewnętrznia się w kolejności wyrazów formuły „wspólne dobro” (1935) w odróżnieniu od „dobro wspólne” $(1997)^{5}$. „Wykładnia gramatyczna terminu "wspólne dobro« każe uznać prymat państwa jako całości przed jednostką i położyć akcent na obowiązki obywateli wobec państwa. Wspólne dobro to coś, co jest wspólnym celem, celem działania wszystkich członków danej grupy, w tym przypadku obywateli”'.

Co się tyczy Konstytucji z 1997 r., to należy uznać pogląd, że formuła „dobro wspólne” zasadniczo różni się od formuły „wspólne dobro” i daje wyraz prymatowi jednostki przed państwem ${ }^{7}$. Innymi słowy, daje wyraz innej koncepcji praw i wolności jednostki będącej pochodną określonej koncepcji państwa. Analiza Konstytucji z 1997 r. prowadzi do wniosku, że państwo polskie jest polityczną organizacją społeczeństwa, w której system organów władzy (organów państwa) jest zaledwie elementem struktury państwa, a nie elementem definiującym państwo. Jest to koncepcja państwa, w którym obywatel i jego organizacje są istotnym elementem współdefiniującym państwo ${ }^{8}$.

Przyjęta w art. 1 Konstytucji formuła „dobra wspólnego” i pośrednio wynikająca z niej koncepcja państwa charakteryzuje koncepcję praw i wolności przyjętą w naszej Konstytucji i jest jednocześnie jej elementem. Jest to bez wątpienia indywidualistyczna koncepcja praw jednostki. Rozstrzyga w ten sposób pytanie: jednostka dla państwa czy państwo dla jednostki - na rzecz służebnej roli państwa wobec obywateli z zachowaniem oczywiście tych wartości, które stanowią o bycie państwa, wartości, o których przede wszystkim mowa w art. 5 Konstytucji, który stanowi, że „Rzeczpospolita Polska strzeże niepodległości i nienaruszalności swojego terytorium, zapewnia wolności

\footnotetext{
${ }^{4}$ Istotny fragment tej dyskusji cytuje: A. Piechowiak, op. cit., s. 10.

${ }^{5}$ Zob. ibidem, s. 9-10.

${ }^{6}$ Ibidem, s. 9.

${ }^{7}$ Zob. ibidem, s. 9-10.

${ }^{8}$ Zob. o tym J. Trzciński, Tendencje i kierunki rozwojowe europejskiego i konstytucjonalizmu, w: Z. Czeszejko-Sochacki (red.), Konstytucja Federalna Szwajcarskiej Konfederacji i Konstytucja Rzeczypospolitej Polskiej z 1997 r., Białystok 2001, s. 27-28.
} 
i prawa człowieka i obywatela oraz bezpieczeństwo obywateli, strzeże dziedzictwa narodowego oraz zapewnia ochronę środowiska, kierując się zasadą zrównoważonego rozwoju".

Ale nawet i te wartości w konkretnych sytuacjach mogą być przecież konfrontowane $\mathrm{z}$ wartościami i prawami jednostki - albo przez odniesienie do art. 2, albo przez odniesienie do art. 31 ust. 3 Konstytucji, a więc do zasady proporcjonalności ograniczania praw.

III. Dotychczasowe uwagi uprawniaja do zgłoszenia następującej tezy metodologicznej, będącej uogólnieniem konkluzji płynących z interpretacji tych postanowień Konstytucji, które używaja pojęcia dobra wspólnego na określenie Rzeczypospolitej. Otóż uważam, że przyjęta koncepcja Rzeczypospolitej Polskiej jako „dobra wspólnego” wszystkich obywateli nie tylko pozostaje we wzajemnym związku z koncepcją państwa przyjętą w Konstytucji i z koncepcja wolności i praw jednostki, ale także wyznacza obszary regulacji konstytucyjnych majace podstawowe znaczenie dla opisania treści formuły „Rzeczpospolita Polska jest dobrem wspólnym wszystkich obywateli”. Zaliczyć do nich należy te, które dla zachowania ładu konstytucyjnego mają podstawowe znaczenie:

a) obszar wolności, praw i obowiązków jednostki, który opisuje nie tylko status jednostki w państwie, ale także opisuje obowiązi władzy (państwa) wobec jednostki,

b) obszar funkcjonowania instytucji życia publicznego. Idzie tu o wybór optymalnego modelu ustroju państwa z punktu widzenia zachowania ładu konstytucyjnego mającego znaczenie dla statusu jednostki,

c) obszar stanowienia prawa będącego podstawowym instrumentem realizacji wartości konstytucyjnych.

Propozycja, aby rozważań nad zagadnieniem Rzeczypospolitej Polskiej jako dobra wspólnego nie ograniczać, jak się to zwykło czynić, jedynie do pierwszego z wymienionych obszarów, a więc obszaru wolności i praw jednostki w zderzeniu z konstytucyjnie określonym interesem państwa ${ }^{9}$, lecz aby je rozciagnaćc na obszary definiujące władzę państwowa - bierze się z przekonania, że formuła dobra wspólnego „działa w obie strony”. Oznacza to, że dbałość o państwo jako dobro wspólne, będące demokratycznym państwem prawnym realizującym zasady sprawiedliwości społecznej (art. 2 Konstytucji), obciąża nie tylko obywatela, ale że obywatel ma także prawo oczekiwać, iż władza publiczna tak będzie działać, aby Rzeczpospolita także przez obywateli mogła być uznana za dobro wspólne.

IV. Podstawowym warunkiem uznania „dobra” (czyt. państwa) za „dobro wspólne” jest takie ukształtowanie instytucji praw, wolności i obowiązków jednostki, które zapewni jednostce realizację przyznanych jej konstytucyjnie praw. Wydaje się, przy wszystkich zastrzeżeniach, jakie tu można zgłosić, że takimi prawami stanowiącymi o istocie instytucji wolności i praw w ramach koncepcji dobra wspólnego są:

9 Zob. B. Lewaszkiewicz-Petrykowska, op. cit. 
a) zasada poszanowania godności ludzkiej stanowiącej źródło wolności i praw człowieka i obywatela (art. 30 i wstęp do Konstytucji),

b) zasada równości praw i równości w prawie deklarująca, że wszyscy sa równi wobec prawa i że wszyscy mają prawo do równego traktowania przez władze publiczne (art. 32),

c) zasada sprawiedliwości społecznej (art. 2), której zastosowanie ma znaczenie przede wszystkim w obszarach praw ekonomicznych i socjalnych,

d) zasada solidarności (solidaryzmu społecznego - wstęp do Konstytucji i art. 20), która rzuca także światło na rozumienie zarówno zasady równości jak i sprawiedliwości społecznej ${ }^{10}$,

e) prawo do sądu (art. 45 ust. 1 Konstytucji) jako gwarancja realizacji praw jednostki.

Wytypowane powyżej prawa, które maja, moim zdaniem, zasadnicze znaczenie dla oceny instytucji wolności i praw jednostki, charakteryzuja się tym, że zabezpieczają możliwość korzystania przez jednostkę z jej praw z uwzględnieniem praw innych osób, ale jednocześnie pozwalają - ze względu na solidarność, równość i sprawiedliwość społeczna - prawa jednostki krępować, właśnie ze względu na zachowanie ładu konstytucyjnego w obrębie dobra wspólnego.

Głębokość korzystania z wolności i praw jednostki w ramach „dobra wspólnego" wyznaczają dwa czynniki, których ocena nie może pozostać bez znaczenia dla opisu instytucji praw i wolności w ramach RP jako „dobra wspólnego”. Są to instytucje obowiązków obywatela, które są swojego rodzaju kontrybucja na rzecz ogółu społeczeństwa (art. 82-86) oraz art. 31 ust. 3 zezwalający na ograniczenie wolności i praw jednostki.

Zagadnienie podstawowych obowiązków jednostki, które z woli Konstytucji uznane są za konieczne do wprowadzenia dla powodzenia „dobra wspólnego” uznanego w tym kontekście za zapewnienie pewnych zadań publicznych w interesie wszystkich obywateli, uregulowane jest w art. 82 do 86 Konstytucji.

Konstytucja zalicza do nich:

- obowiązek wierności Rzeczpospolitej oraz troskę o dobro wspólne (art. 82),

- obowiązek przestrzegania prawa RP (art. 83),

- obowiązek ponoszenia ciężarów i świadczeń publicznych (art. 84),

- obowiązek obrony ojczyzny (art. 85),

- obowiązek dbałości o stan środowiska (art. 86).

Inną forma ograniczenia wolności i praw przewidzianą w Konstytucji jest przede wszystkim art. 31 ust. 3 Konstytucji, ale także art. 61 ust. 3 i art. $22^{11}$.

${ }^{10} \mathrm{O}$ związku tych zasad, a w szczególności zasady solidarności z zasadą dobra wspólnego wyrażoną w art. 1 Konstytucji, zob. Wystapienie Prezydenta Aleksandra Kwaśniewskiego, op. cit. Zob. też J. Kurys, Sprawiedliwość społeczna. Szkice ze wspótczesnej teorii konstytucjonalizmu i praktyki polskiego prawa ustrojowego, Kraków 2004.

${ }^{11}$ Art. 31: „1. Wolność człowieka podlega ochronie prawnej. 2. Każdy jest obowiązany szanować wolności i prawa innych. Nikogo nie wolno zmuszać do czynienia tego, czego prawo mu nie nakazuje. 3. Ograniczenia w zakresie korzystania z konstytucyjnych wolności i praw moga być ustanawiane tylko w ustawie i tylko wtedy, gdy sa konieczne w demokratycznym państwie dla jego bezpieczeństwa lub porządku publicznego, bądź dla ochrony środowiska, zdrowia i moralności publicznej, albo wolności i praw innych osób. Ograniczenia te nie mogą naruszać istoty wolności i praw”. Art. 61 ust. 3: „Ograniczenie prawa, o którym mowa w ust. 1 i 2, może nastapić 
Analiza tych przepisów pokazuje, że jakkolwiek nie używają one sformułowania, że ograniczenie może nastapić ze względu na przesłankę „dobra wspólnego", to szczegółowe przesłanki art. 31 ust. 3, art. 61 ust. 3 i art. $22 \mathrm{w}$ istocie tak sa skonstruowane, że mogłyby wyczerpywać swoją treścią pojęcie dobra wspólnego. Należą do nich: ochrona bezpieczeństwa państwa i porządku publicznego, ochrona środowiska, ochrona zdrowia i moralności publicznej, ochrona ważnego interesu gospodarczego państwa, ochrona wolności i praw innych osób, interes publiczny. Bez wątpienia cytowane tu przepisy art. 31 ust. 3, art. 22 i art. 61 ust. 3 , a także art. 82-86 mają swój prosty zwiazek z art. 1 Konstytucji; koncepcyjnie z niego wypływają i go opisuja.

V. Drugim z wyznaczonych przeze mnie obszarów materii konstytucyjnej majacym znaczenie dla zdefiniowania treści formuły, według której „Rzeczpospolita Polska jest dobrem wspólnym wszystkich obywateli”, jest obszar funkcjonowania instytucji publicznych składających się na system organów władzy publicznej, a więc ważny element struktury państwa.

Jeżeli prawdziwa jest teza, że państwo i jego organy mają określone obowiąki wobec obywateli opisane w Konstytucji ${ }^{12}$, a także wynikajacce z istoty demokratycznego państwa prawnego ${ }^{13}$, to minimalne postulaty realizacji dobra wspólnego przez organy władzy (w Konstytucji używa się formuły państwo) ${ }^{14}$ polegają na tym, że instytucje publiczne mają działać sprawnie ${ }^{15}$ i sprawiedliwie w interesie społeczeństwa. Aby osiagnać powyższe cele, powinny być zorganizowane demokratycznie ${ }^{16}$. Ten ostatni postulat oznacza możliwość wpływania przez obywateli za pomoca przyznanych im środków i instytucji prawnych (np. referendum) na kształt i treść decyzji państwowych. Brak takich możliwości prowadziłby do alienacji instytucji publicznych i do podważenia tezy o tym, że RP jest dobrem wspólnym wszystkich obywateli. Coś, co nie jest społecz-

wyłącznie ze względu na określone w ustawach ochronę wolności i praw innych osób i podmiotów gospodarczych oraz ochronę porządku publicznego, bezpieczeństwa lub ważnego interesu gospodarczego państwa”. Art. 22: „Ograniczenie wolności działalności gospodarczej jest dopuszczalne tylko w drodze ustawy i tylko ze względu na ważny interes publiczny”.

${ }^{12}$ Np. art. 68 ust. 3: „Władze publiczne są obowiązane do zapewnienia szczególnej opieki zdrowotnej dzieciom, kobietom ciężarnym, osobom niepełnosprawnym i osobom w podeszłym wieku” albo art. 71 ust. 1: „Państwo w swojej polityce społecznej i gospodarczej uwzględnia dobro rodziny. Rodziny znajdujące się w trudnej sytuacji materialnej i społecznej, zwłaszcza wielodzietne i niepełne, mają prawo do szczególnej pomocy ze strony władz publicznych". I choć adresatem tych postanowień jest przede wszystkim „państwo”, to przecież jest w nich zawarte minimum praw dla obywatela. Zob. o tym J. Trzciński, Komentarz do art. 68 Konstytucji, w: L. Garlicki (red.), Konstytucja Rzeczypospolitej Polskiej. Komentarz, t. 3, Warszawa 2003.

${ }^{13}$ Mam tu na uwadze choćby formułę art. 2 Konstytucji nakazująca, aby Rzeczpospolita była państwem demokratycznym, lub art. 4 ust. 2, że: „naród sprawuje władzę przez swoich przedstawicieli lub bezpośrednio".

${ }^{14} \mathrm{~W}$ istocie na gruncie prawa kompetencja łączy się nie z państwem, lecz z organami państwa, czy szerzej - organami władzy publicznej.

${ }^{15} \mathrm{Na}$ związek sprawnego działania aparatu państwowego z dobrem wspólnym zwraca też uwage P. Winczorek w opinii z 3 lipca 2002 r. w sprawie interpretacji art. 203 Konstytucji RP w związku z art. 2 ustawy o NIK (zob. maszynopis, s. 2), a także TK w orzeczeniu K 24/02.

${ }^{16}$ Realizacja postulatu trójpodziału władzy jest warunkiem koniecznym, ale nie wystarczającym do zrealizowania tego celu. 
nie akceptowane, trudno nazwać dobrem wspólnym. Na przykład nie będzie dobrem wspólnym system państwowy oparty na dyktaturze czy dominującej ideologii narzuconej społeczeństwu.

VI. Trzecim obszarem majacym znaczenie dla identyfikacji treści formuły „Rzeczpospolita Polska jest dobrem wspólnym wszystkich obywateli” jest obszar reguł stanowienia prawa i treści samego prawa, które, aby mogło skutecznie być uważane za element dobra wspólnego, musi spełniać trzy warunki:

a) używając formuły art. 1 Konstytucji: „wszyscy obywatele” (społeczeństwo) powinni identyfikować się z treścia prawa w stopniu, w jakim uwzględnia ono interesy społeczeństwa ${ }^{17}$ opisane w postanowieniach Konstytucji określajacych cele i zadania państwa (Rzeczypospolitej Polskiej),

b) społeczeństwo ma instytucjonalny wpływ na proces tworzenia prawa, tzn. że procedury stanowienia prawa uwzględniają postulat demokratyczności prawa,

c) prawo musi być zgodne z Konstytucja, ustawą zasadniczą Rzeczypospolitej Polskiej, której powinna przysługiwać cecha względnej stabilności, ze względu na wartości, które formułuje. Wartościami tymi są demokratyczny ustrój państwowy i wolności i prawa jednostki.

VII. Orzecznictwo sądowe ${ }^{18} \mathrm{w}$ małym stopniu odwołuje się do art. 1 Konstytucji. Najliczniejsze ślady sięgania do zasady opisanej w art. 1 znajdziemy w orzecznictwie TK $^{19}$.

Jako wzorzec konstytucyjny nie występuje wprost w orzecznictwie TK, co może oznaczać, że wnioskujący lub skarżący nie widzą niezgodności poszczególnych przepisów ustawy z art. 1 Konstytucji albo uważaja, że art. 1 nie mógłby występować jako samodzielny wzorzec. Moim zdaniem nie można mieć wątpliwości co do normatywnego charakteru art. 1 Konstytucji i co do tego,

17 Zagadnienie to jest niekiedy ujmowane jako zagadnienie „prawowitości” prawa, dla której stwierdzenia ważne jest, aby prawo było zgodne z interesem i preferencjami jednostek. Zob. W. Sadurski, Status jednostki w prawie: refleksje filozoficzno-prawne na temat prawowitości demokracji (tezy referatu), Konferencja na Wydziale Prawa i Administracji UW Warszawa, 25 czerwca 2005 r. (maszynopis).

${ }^{18}$ Znane mi orzecznictwo SN nie odwołuje się wprost do art. 1 Konstytucji. NSA odwołał się do art. 1 Konstytucji w orzeczeniu z 12 kwietnia 2000 r., I SA/Ka 1740/98. W wyroku tym NSA dokonał interpretacji art. 9 k.p.a. przez pryzmat art. 1 Konstytucji. Oto teza tego wyroku wyjęta z uzasadnienia: „Obowiązek informowania i wyjaśniania stronom przez organ prowadzący postępowanie całokształtu okoliczności faktycznych i prawnych toczącej się sprawy (art. 9 Kpa) powinien być rozumiany tak szeroko, jak to jest możliwe. Udowodnione naruszenie tego obowiązku powinno być rozumiane jako wystarczająca podstawa do uchylenia decyzji, szczególnie wówczas, gdy urzędnik stwierdza (lub powinien stwierdzić), że strona zamierza podjacć działania wiążące się dla niej z niekorzystnymi skutkami, lub nawet ryzykiem wystapienia podobnych skutków. W takim wypadku urzędnik ma wyraźny obowiązek w możliwie jasny sposób wyjaśnić całość okoliczności sprawy stronie i równie wyraźnie wskazać na ryzyko wiążące się z zaplanowanymi działaniami. Jest to jedyny odpowiadajaccy zasadzie art. 1 Konstytucji sposób rozumienia art. 9 Kpa”.

19 Zob. wyroki TK: z 12 kwietnia 2000 r., K 8/98; z 30 stycznia 2001 r., K 17/00; z 10 października 2001 r., K 28/01; z 18 lutego 2003 r., K 24/02; z 25 listopada 2003 r., K 37/02; z 7 stycznia 2004 r., K $14 / 03$. 
czy art. 1 mógłby być wzorcem konstytucyjnym przy kontroli konstytucyjności prawa, może z wyjątkiem skargi konstytucyjnej.

Występuje natomiast art. 1 i użyte w nim pojęcie „dobro wspólne” jako argument wzmacniający konkretne rozstrzygnięcia oparte na konkretnych wartościach konstytucyjnych, przede wszystkim - solidarności (solidaryzm), sprawiedliwości społecznej, równości, demokratycznym państwie prawnym.

Zagadnienie „dobra wspólnego” w kontekście zasady solidarności społecznej zostało użyte w wyroku TK z 30 stycznia 2001 r. (K 1700). Odwołując się do zasady solidarności społecznej, TK uznał, że nie tylko pracownicy, lecz także pracodawcy musza ponieść pewne, określone koszty reformy płacowej (ubruttowienie wynagrodzeń pracowników) i że jest to zgodne z zasadą wyrażoną w art. 1 Konstytucji. Trybunał stwierdził, że wszyscy obywatele zarówno pracodawcy, jak i pracownicy sa w stopniu odpowiednim do swoich możliwości zobowiązani do poświęcenia pewnych interesów własnych dla „dobra wspólnego".

Zagadnienie dobra wspólnego (art. 1) w kontekście zasady państwa prawnego (art. 2) pojawia się w dwóch aspektach: w związku dobra wspólnego z zasadą sprawiedliwości społecznej, przez która realizuje się zasada dobra wspólnego (K 8/98) i w związku z taką organizacją samorządu terytorialnego, która zapewni zdolność wykonywania zadań publicznych w interesie dobra wspólnego.

Niekiedy też w uzasadnieniach wyroków TK dobro wspólne występuje w kontekście ograniczenia praw jednostki (np. ze względu na bezpieczeństwo państwa K 37/02), a w orzeczeniu K 14/03 mówi się o związku odpowiedniego modelu ustawy ze względu na zapewnienie praw wszystkich obywateli (a więc dobra wspólnego).

VIII. Powyżej sformułowane uwagi, z których większość ma charakter uwag metodologicznych, tzn. pokazujących sposób podejścia do badań nad zasadą wyrażoną w art. 1 Konstytucji, prowadzą mnie do następujących uogólnień:

a) próba rozumienia zasady „Rzeczpospolita Polska jest dobrem wspólnym wszystkich obywateli” musi za punkt wyjścia w tle badań mieć koncepcję państwa zakodowaną w Konstytucji. „Dobro wspólne” jest pochodną koncepcji państwa zarówno w płaszczyźnie koncepcji wolności i praw jednostki, jak i w płaszczyźnie organizacyjnej państwa (czyt. władzy publicznej),

b) na płaszczyźnie konstytucyjnej dobro wspólne nie redukuje się do zagadnienia ograniczenia wolności i praw jednostki w zestawieniu z interesem publicznym (interesem państwa). Zagadnienie należy widzieć także w płaszczyźnie ustrojowej, w płaszczyźnie ładu konstytucyjnego, akceptowanego lub nie przez obywateli,

c) z pojęciem „dobro wspólne” (Rzeczpospolita Polska) łączą się nie tylko obowiazki obywatela wobec państwa, ale i obowiąki państwa wobec obywatela. Ślady takiego rozumowania są wyraźnie zaznaczone w art. 2 Konstytucji określającym Rzeczpospolitą Polską jako demokratyczne państwo prawne urzeczywistniające zasady sprawiedliwości społecznej, 
d) wydaje się, że w obecnym stanie badań nad zagadnieniem art. 1 Konstytucji wszelkie uogólnienia szczegółowych uwag poczynionych powyżej byłyby przedwczesne przede wszystkim dlatego, że zbyt skapa jest praktyka sądowa i trybunalska w tym względzie, a bez niej nie da się odpowiedzieć w pogłębiony sposób na pytanie o treść zasady, że „Rzeczpospolita Polska jest dobrem wspólnym wszystkich obywateli”.

\author{
prof. dr hab. Janusz Trzciński \\ Uniwersytet Warszawski \\ jtrzcinski@nsa.gov.pl
}

\title{
THE REPUBLIC OF POLAND - THE COMMON GOOD OF ALL CITIZENS
}

\section{Sum mary}

The aim of this article is to propose a methodology for research into the constitutional principle of the common good (Article 1 of the Polish Constitution). The author takes the view that the basic condition for the recognition of a state as a common good is to ensure that the rights, freedoms and duties of an individual are shaped in such a way as to ensure that the individual's constitutional rights can be exercised. The laws that constitute the essence of the institutions of the freedom and rights within the concept of the common good include: human dignity, equality in law, the principle of social justice, the principle of social solidarity, the right to a trial. The minimum requirements for authorities to pursue the common good are that public institutions act efficiently and fairly in the interest of society. Common good is a derivative of the concept of state regarding both, the concept of freedom and individual rights, and the organisational side of the state. On the constitutional level, the common good is not reduced to the issue of the limitation of individual freedoms and rights as compared to the public (State) interest. This issue should also be noted at the political level, the State's constitutional order, whether accepted or not by the citizens. The concept of the common good is not only associated with the citizen's duties towards the state, but also with the state's duties towards the citizen. The closest context in which Article 1 of the Constitution should be read is Article 2 of the Constitution (the principle of a democratic state governed by law), since the two, taken together, define the Republic of Poland as a state. 
